\title{
PERANAN DANA PIHAK KETIGA DALAM KEGIATAN USAHA MIKRO KECIL DAN MENENGAH PADA BANK SYARIAH
}

\author{
Wahyu Syarvina \\ Sekolah Tinggi Ekonomi dan Bisnis Islam Al Ulum Terpadu Medan
}

\begin{abstract}
Third Party Funds (DPK) may affect the bank's budget. If third party funds increase, then the bank's budget will increase as well. If Third Party Funds decreases, it can weaken the operational activities of sharia banks. The growth of third party funds becomes very important, namely to provide greater financing to prospective customers and also for the development of people's economy, especially in the real sector. Sharia banks are expected to be contributors from financial institutions for economic growth as measured by the growth of the real sector. MSMEs in the Indonesian economy have a very important role in improving the competitiveness of microeconomics. The role of MSMEs is known as a sector that can absorb large labor nationally, accommodate the role of the poor in the economic structure, and is a potentially large sector that contributes to GDP. The government and related parties are obliged to take a leading position in encouraging this sector to grow better. So the economic development of society is getting better, poverty alleviation and unemployment problem can be solved well. Then third party funds in this case should be the concern of each sharia bank.
\end{abstract}

Keywords : Third Party Funds, MSMEs, Bank, Sharia

\section{Abstrak}

Dana Pihak Ketiga (DPK) dapat mempengaruhi anggaran bank. Jika dana pihak ketiga meningkat, maka anggaran bank akan meningkat juga. Jika Dana Pihak Ketiga menurun, itu dapat melemahkan kegiatan operasional bank syariah. Pertumbuhan dana pihak ketiga menjadi sangat penting, yaitu untuk memberikan pembiayaan yang semakin besar kepada calon nasabah dan juga untuk perkembangan ekonomi rakyat khususnya di sektor riil. Bank syariah diharapkan dapat menjadi penyumbang dari lembaga keuangan untuk pertumbuhan ekonomi yang diukur dengan pertumbuhan sektor riil. Usaha Mikro Kecil dan Menengah dalam perekonomian Indonesia memiliki peran yang sangat penting dalam rangka meningkatkan daya saing ekonomi mikro. Peran UMKM dikenal sebagai sektor 
yang dapat menyerap tenaga kerja besar secara nasional, mengakomodasi peran masyarakat miskin di struktur ekonomi, dan merupakan sektor berpotensi besar yang berkontribusi terhadap PDB. Pemerintah dan pihak terkait berkewajiban untuk mengambil posisi terdepan dalam mendorong sektor ini untuk tumbuh lebih baik. Jadi perkembangan ekonomi masyarakat semakin baik, pengentasan kemiskinan serta masalah pengangguran dapat diselesaikan dengan baik. Maka dana pihak ketiga dalam hal ini harus menjadi perhatian masing-masing bank syariah.

Kata kunci : DPK, UMKM, bank, syariah

\section{Pendahuluan}

Indonesia merupakan Negara dengan penduduk muslim terbesar di dunia. Dengan banyaknya penduduk yang beragama Islam menjadikan Indonesia sebagai Negara yang potensial dalam pengembangan perbankan syariah. Perkembangan perbankan syariah di Indonesia telah menjadi tolak ukur atas keberhasilannya mampu bertahan dari krisis moneter pada tahun 1998, dimana banyaknya bank konvensional yang dilikuidasi akibat kegagalan sistem bunga. Sedangkan perbankan yang menerapkan prinsip syariah mampu bertahan dan terus berjalan sampai saat ini. Langkah yang telah dilakukan untuk mengembangkan perbankan syariah adalah pemberian izin kepada bank umum konvensional untuk membuka kantor cabang Unit Usaha Syariah (UUS) atau dengan mengkonversi sebuah bank konvensional menjadi Bank Syariah.

Keunggulan yang dimiliki oleh perbankan syariah adalah peraturannya dimana kewenangan dalam mengeluarkan fatwa syariah terpusat pada satu lembaga independen yaitu Dewan Syariah Nasional dari Majelis Ulama (MUI). Selain Dewan Syariah Nasional lembaga independen yang lain adalah Dewan Pengawas Syariah yang bertugas melakukan pengawasan syariah dalam opearsional perbankan syariah.

Regulator lain yang sangat mendukung perkembangan perbankan syariah adalah Bank Indonesia. Peran pihak regulator dalam operasional perbankan syariah, yaitu Bank Indonesia (BI), Dewan Syariah Nasional (DSN) dan Dewan Pengawas Syariah (DPS) dan manajemen operasional perbankan sendiri menjadi 
penting untuk meningkatkan perkembangan dan kinerja perbankan syariah di Indonesia.

Di dalam penerapan kegiatan usaha pada perbankan syariah di Indonesia pemerintah telah mengeluarkan beberapa peraturan sehubungan dengan kegiatan usaha yang akan dilakukan pada Bank Umum Syariah dan Unit Usaha Syariah maupun Bank Pembiayaan Rakyat Syariah. Bank Indonesia telah membuat ketentuan mengenai akad penghimpunan dan penyaluran dana bagi bank yang melakukan kegiatan usaha berdasarkan prinsip syariah dalam PBI No. 7/46/PBI/2005.

Pertumbuhan dana pihak ketiga menjadi sangat penting untuk tetap terjaga pertumbuhannya, yaitu tidak lain untuk kepentingan semakin masifnya pembiayaan yang akan diberikan bank kepada calon nasabah pembiayaannya dan untuk mengembangkan ekonomi masyarakat di sektor riil. Pertumbuhan ekonomi yang diukur dari pertumbuhan sektor riil tentunya sangat berharap bank syariah bisa menjadi kontributor dalam salah satu lembaga keuangan yang pro sektor riil. Usaha Mikro Kecil dan Menengah (UMKM) dalam perekonomian Indonesia memiliki peranan yang sangat penting dalam rangka meningkatkan daya saing perekonomian secara mikro, peranan ini antara lain sektor UMKM dikenal sebagai sektor yang dapat menyerap tenaga kerja dalam jumlah besar secara nasional, mengakomodasi peran masyarakat miskin dalam struktur ekonomi, serta merupakan sektor yang berpotensi besar memberikan sumbangan pada PDB. Maka dari itu merupakan suatu kewajiban bagi pemerintah dan pihak-pihak terkait mengambil posisi terdepan dalam mendorong sektor ini berkembang dengan lebih baik. Sehingga perkembangan ekonomi masyarakat semakin membaik dan pengentasan kemiskinan juga masalah pengangguran bisa teratasi dengan baik. Maka posisi dana pihak ketiga dalam hal ini harus menjadi perhatian masingmasing bank syariah.

Untuk mendorong tumbuh dan berkembangnya UMKM di Negara ini, dibutuhkan peran serta aktif perbankan syariah sebagai lembaga keuangan yang bertugas menghimpun dana dari masyarakat dan menyalurkannya kembali untuk masyarakat. Sebagaimana yang kita ketahui selama krisis ekonomi, bank syariah merupakan bank yang tidak terpengaruh oleh krisis tersebut. Bank syariah juga mendorong tumbuh dan berkembangnya sektor UMKM yang ditunjukkan dengan 
berbagai strategi seperti pembukaan pusat-pusat pelayanan pembiayaan mikro seperti gerai UMKM atau sentra UMKM.

Bank Indonesia (BI) mencatat penyaluran pembiayaan syariah pada sektor usaha mikro, kecil, dan menengah (UMKM) mencapai 70\% dari total pembiayaan, atau sebesar Rp. 58 triliun hingga akhir September 2012. Bisa kita lihat hasilnya ketika bank syariah bersinergi dengan UMKM, dimana keduanya memiliki ketahanan menghadapi krisis akan menjadikan perekonomian Indonesia semakin stabil.

Dana Pihak Ketiga (DPK) adalah dana nasabah yang disalurkan kepada bank dan menjadi aset terbesar yang dimiliki oleh bank syariah. Pertumbuhan setiap bank sangat dipengaruhi oleh perkembangan kemampuannya menghimpun dana masyarakat, baik berskala kecil maupun besar dengan masa pengendapan yang memadai. Sebagai lembaga keuangan, maka dana merupakan masalah utama bagi setiap bank. Tanpa dana yang cukup, maka bank tidak dapat berbuat apa-apa atau dengan kata lain bank menjadi tidak berfungsi sama sekali. Semakin tinggi Dana Pihak Ketiga yang dimiliki oleh bank syariah, maka akan semakin banyak jumlah dana yang akan disalurkan bank kepada masyarakat dalam bentuk pembiayaan. Dana titipan dari Dana Pihak Ketiga yang sudah terkumpul tersebut disalurkan bank kepada masyarakat melalui pembiayaan, dengan menganalisa pembiayaan nasabah yang mengajukan pembiayaan dengan melihat jenis usaha, lama usaha, dan jaminan (agunan) yang diberikan nasabah ke bank syariah tersebut.

Bank Syariah tidak menyalurkan dana kepada nasabah yang ingin membuka usaha yang melanggar syariat Islam, seperti membuka tempat perjudian, diskotik, dan tempat pembuatan senjata ilegal dan lain sebagainya. Sedangkan untuk pembiayaan yang sifatnya konsumtif seperti, pembiayaan rumah, pembelian properti, untuk pembangunan rumah/renovasi rumah biasanya bank syariah menganalisa dari pendapatan nasabah tersebut perbulan, apabila penghasilannya mengcover maka pembiayaannya akan diberikan.

Pada umumnya pelaksanaan akad wadiah (titipan) dan mudharabah dalam bank syariah banyak diterapkan pada pembiayaan usaha mikro kecil dan menengah baik pada Bank Umum Syariah maupun Unit Usaha Syariah (UUS). Dalam hal penyaluran dana pembiayaan dapat disesuaikan dengan kebutuhan 
nasabah. Produk pembiayaan perbankan syariah mengacu pada pembiayaan usaha mikro kecil dan menengah. Konsep seperti ini memberi peluang bagi usaha kecil menengah untuk mengembangkan usahanya berdasarkan kemitraan.

\section{Dana Pihak Ketiga (DPK)}

Yang dimaksud dengan pihak ketiga adalah seseorang yang tidak terlibat langsung dalam transaksi. Dana Pihak Ketiga (DPK) merupakan dana yang dihasilkan bank syariah dari produk penghimpunan dana dari masyarakat, seperti tabungan, giro dan deposito. Dana-dana yang dihimpun dari masyarakat ini merupakan sumber dana terbesar yang paling diandalkan oleh bank. Sesuai pasal 21 Undang-Undang No. 21 tahun 2008 tentang Perbankan Syariah dalam menghimpun dana dari masyarakat adalah dalam bentuk simpanan tabungan, simpanan giro dan simpanan deposito.

Dalam sembilan tahun terakhir (2005-2013), pendanaan atau dan pihak ketiga (DPK) perbankan syariah Indonesia mengalami peningkatan dari tahun ke tahun secara nominal, sedangkan pertumbuhannya secara keseluruhan meningkat meskipun sempat melambat pada tahun 2012. Giro meningkat lebih dari sembilan kali dari Rp. 2 triliun menjadi Rp. 18,5 triliun, dengan pertumbuhan yang melambat dari tahun 2009 hingga naik lagi mencapai 47,4\% pada tahun 2012 dan akhirnya turun tajam menjadi 4,6\% pada tahun 2013. Tabungan meningkat tiga belas kali dari Rp. 4,4 triliun menjadi Rp.57,2 triliun, dengan pertumbuhan yang meningkat terus dari tahun 2008 hingga mencapai 42,3\% pada tahun 2011 dan akhirnya turun menjadi $26,9 \%$ di tahun 2013. Deposito meningkat lebih dari sebelas kali lipat dari Rp. 9,2 triliun menjadi Rp. 107,8 triliun dengan pertumbuhan yang meningkat terus dari tahun dari tahun 2007 hingga mencapai $60,7 \%$ pada tahun 2011 namun turun menjadi $27,2 \%$ pada $2013 .{ }^{1}$

\section{Tabungan}

Yang dimaksud dengan tabungan adalah sebagian pendapatan masyarakat yang tidak dibelanjakan, disimpan sebagai cadangan untuk berjaga-jaga dalam jangka pendek atau masa yang akan datang. Menurut Undang-Undang Perbankan No. 10 Tahun 1998, Tabungan adalah simpanan yang penarikannya hanya dapat dilakukan menurut syarat tertentu yang disepakati, tetapi tidak dapat ditarik dengan cek, bilyet giro dan atau alat lainnya yang dipersamakan dengan itu. Sarana dalam penarikan tabungan adalah :

- Buku tabungan 
- Slip penarikan

- ATM (Anjungan Tunai Mandiri)

- Sarana Lainnya (Formulir Transfer, Internet Banking, Mobile Banking, dll)

Faktor-faktor yang mempengaruhi tingkat tabungan adalah :

- Tinggi rendahnya tingkat pendapatan masyarakat.

- Tinggi rendahnya tingkat suku bunga bank

- Adanya tingkat kepercayaan terhadap bank

Menurut Undang-Undang Perbankan Syariah No. 21 Tahun 2008, tabungan adalah simpanan berdasarkan akad wadi'ah atau Investasi dana berdasarkan akad mudharabah atau akad lain yang tidak bertentangan dengan prinsip syariah yang penarikannya hanya dapat dilakukan menurut syarat dan ketentuan tertentu yang disepakati, tetapi tidak dapat ditarik dengan cek, bilyet giro, dan/atau alat lainnya yang dipersamakan dengan itu. Menurut Fatwa Dewan Syariah Nasional tabungan ada dua jenis, yaitu :

a. Tabungan yang tidak dibenarkan secara syariah, yaitu tabungan yang - berdasarkan perhitungan bunga.

b. Tabungan yang dibenarkan yang secara syariah, yaitu tabungan yang berdasarkan prinsip mudharabah dan wadiah.

\section{Tabungan Wadiah}

Tabungan wadiah adalah tabungan yang dijalankan berdasarkan akad wadiah, yaitu titipan murni yang harus dijaga dan dikembalikan setiap saat sesuai dengan kehendak pemiliknya. Dalam produk tabungan wadiah, Bank Syariah menggunakan akan wadiah yad adh-dhamanah. Dalam hal ini, nasabah bertindak sebagai penitip yang memberikan hak kepada Bank Syariah untuk menggunakan atau memanfaatkan uang atau barang titipannya, sedangkan Bank Syariah bertindak sebagai pihak yang dititipi dana atau barang tersebut. Sebagai konsekuensinya, bank bertanggung jawab terhadap keutuhan harta titipan tersebut serta mengembalikannya kapan saja pemiliknya menghendaki. Di sisi lain, bank juga berhak sepenuhnya atas keuntungan dari hasil penggunaan atau pemanfaatan adana atau barang tersebut. Ketentuan umum tabungan berdasarkan wadiah : ${ }^{2}$

- Bersifat simpanan

- Simpanan bisa diambil kapan saja (on call) atau berdasarkan kesepakatan. 
- Tidak ada imbalan yang disyaratkan, kecuali dalam bentuk pemberian ('athaya) yang bersifat sukarela dari pihak bank.

\section{Tabungan Mudharabah}

Tabungan mudharabah adalah tabungan yang dijalankan berdasarkan akad mudharabah. Mudharabah mempunyai dua bentuk, yaitu mudharabah mutlaqah dan mudharabah muqayyadah, dimana perbedaannya terletak pada ada atau tidak nya persyaratan yang diberikan pemilik dana kepada bank dalam mengelola hartanya. Dalam hal ini, Bank Syariah bertindak sebagai mudharib (pengelola dana), sedangkan nasabah bertindak sebagai shahibul mal (pemilik dana). Dari hasil pengelolaan dana mudharabah, Bank Syariah akan membagihasilkan kepada pemilik dana sesuai dengan nisbah yang telah disepakati dan dituangkan dalam akad pembukaan rekening. Dalam mengelola dana tersebut, bank tidak bertanggung jawab terhadap kerugian yang bukan disebabkan oleh kelalaiannya. Namun, apabila yang terjadi adalah mismanagement, bank bertanggung jawab penuh terhadap kerugian tersebut. Dalam mengelola harta mudharabah, bank menutup biaya operasional tabungan dengan menggunakan nisbah keuntungan yang menjadi haknya. Di samping itu, bank tidak diperkenankan mengurangi nisbah keuntungan nasabah penabung tanpa persetujuan yang bersangkutan. Sesuai dengan ketentuan yang berlaku, PPH bagi hasil tabungan mudharabah dibebankan langsung ke rekening tabungan mudharabah pada saat perhitungan bagi hasil. Ketentuan umum Tabungan berdasarkan Mudharabah : ${ }^{3}$

- Dalam transaksi ini nasabah bertindak sebagai shahib al-mal atau pemilik dana, dan bank bertindak sebagai mudharib atau pengelola dana

- Dalam kapasitasnya sebagai mudharib, bank dapat melakukan berbagaimacam usaha yang tidak bertentangan dengan prinsip syariah dan mengembangkannya termasuk di dalamnya mudharabah dengan pihak lain.

- Modal harus dinyatakan dalam besaran jumlah, dalam bentuk tunai dan bukan piutang.

- Pembagian keuntungan harus dinyatakan dalam bentuk nisbah dan dituangkan dalam akad pembukaan rekening.

- Bank sebagai mudharib menutup biaya operasional dana tabungan dengan menggunakan nisbah keuntungan yang menjadi haknya 
- Bank tidak diperkenankan mengurangi nisbah keuntungan nasabah tanpa persetujuan yang bersangkutan.

\section{Giro}

Yang dimaksud dengan giro adalah simpanan yang penarikannya dapat dilakukan setiap saat dengan menggunakan cek, bilyet giro, sarana perintah bayar lainnya, atau dengan pemindahbukuan. ${ }^{4}$ Menurut Undang-Undang Perbankan Syariah No. 21 Tahun 2008, giro adalah simpanan berdasarkan akad wadi'ah atau akad lain yang tidak bertentangan dengan prinsip syariah yang penarikannya dapat dilakukan setiap saat dengan menggunakan cek, bilyet giro, sarana perintah pembayaran lainnya, atau dengan perintah pemindahbukuan. Dalam Fatwa Dewan Syariah Nasional, giro ada dua jenis :

a. Giro yang tidak dibenarkan secara syariah, yaitu giro yang berdasarkan perhitungan bunga.

b. Giro yang dibenarkan secara syariah, yaitu giro yang berdasarkan prinsip - mudharabah dan wadiah.

\section{Giro Wadiah}

Yang dimaksud dengan giro wadiah adalah giro yang dijalankan berdasarkan akad wadiah, yakni titipan murni yang setiap saat dapat diambil jika pemiliknya menghendaki. Dalam konsep wadiah yad adh-dhamanah, pihak yang menerima titipan boleh menggunakan atau memanfaatkan uang atau barang yang dititipkan. Dengan demikian, pemilik dana dan bank tidak boleh saling menjanjikan untuk memberikan imbalan atas penggunaan atau pemanfataan dana atau barang titipan tersebut. Dalam kaitan dengan produk giro, Bank Syariah menerapkan prinsip wadiah yad dhamanah, yaitu nasabah bertindak sebagai penitip yang memberikan hak kepada Bank Syariah untuk menggunakan atau memanfaatkan uang atau barang titipannya, sedangkan Bank Syariah bertindak sebagai pihak yang dititipi yang disertai hak untuk mengelola dana titipan dengan tanpa mempunyai kewajiban memberikan bagi hasil dari keuntungan pengelolaan dana tersebut. Namun demikian, Bank Syariah diperkenankan memberikan insentif berupa bonus dengan catatan tidak disyaratkan sebelumnya. Ketentuan umum giro berdasarkan wadiah $:^{5}$

- Bersifat titipan. 
- Titipan bisa diambil kapan saja (on call)

- Tidak ada imbalan yang disyaratkan, kecuali dalam bentuk pemberian ('athaya) yang bersifat sukarela dari pihak bank.

\section{Giro Mudharabah}

Yang dimaksud dengan giro mudharabah adalah giro yang dijalankan berdasarkan akad mudharabah. Dalam hal ini, Bank Syariah bertindak sebagai mudharib (pengelola dana), sedangkan nasabah bertindak sebagai shahibul mal (pemilik dana). Dalam kapasitasnya sebagai mudharib, Bank Syariah dapat melakukan berbagai macam usaha yang tidak bertentangan dengan prinsip syariah serta mengembangkannya, termasuk melakukan akad mudharabah dengan pihak lain. Dari hasil pengelolaan dana mudharabah, Bank Syariah akan membagihasilkan kepada pemilik dana sesuai dengan nisbah yang telah disepakati dan dituangkan dalam akad pembukaan rekening. Dalam mengelola dana tersebut, bank tidak bertanggung jawan terhadap kerugian yang bukan disebabkan kelalaiannya. Namun, apabila yang terjadi adalah mis management, bank bertanggung jawab penuh terhadap kerugian tersebut.

\section{Deposito}

Selain tabungan dan giro, produk penghimpunan Dana Pihak Ketiga Bank Syariah adalah deposito. Berdasarkan Undang-undang Nomor 10 Tahun 1998 tentang Perubahan Atas Undang-Undang Nomor 7 Tahun 1992 tentang Perbankan, yang dimaksud dengan deposito adalah simpanan yang penarikannya hanya dapat dilakukan pada waktu tertentu berdasarkan perjanjian Nasabah Penyimpan dengan bank. Menurut Fatwa Dewan Syariah Nasional, deposito ada dua jenis :

a. Deposito yang tidak dibenarkan secara syariah, yaitu deposito yang berdasarkan perhitungan bunga.

b. Deposito yang dibenarkan secara syariah, yaitu deposito yang berdasarkan prinsip mudharabah.

Deposito biasanya memiliki jangka waktu tertentu dimana uang di dalamnya tidak boleh ditarik nasabah. Deposito boleh dicairkan ketika telah jatuh tempo, biasanya deposito mempunyai jangka waktu jatuh tempo selama 1, 3, 6 dan 12 bulan. Bila deposito dicairkan sebelum jatuh tempo, maka akan dikenakan penalti. Deposito juga dapat diperpanjang dengan menggunakan sistem ARO 
(Automatic Roll Over) yaitu deposito akan diperpanjang otomatis setelah jatuh tempo, sampai pemiliknya mencairkan deposito tersebut.

Menurut Undang-Undang Perbankan Syariah No. 21 Tahun 2008, Deposito adalah Investasi dana berdasarkan Akad mudharabah atau Akad lain yang tidak bertentangan dengan Prinsip Syariah yang penarikannya hanya dapat dilakukan pada waktu tertentu berdasarkan Akad antara Nasabah Penyimpan dan Bank Syariah dan/atau UUS.

Dari hasil pengelolaan dana mudharabah, Bank Syariah akan membagihasilkan kepada pemilik dana sesuai dengan nisbah yang telah disepakati dan dituangkan dalam akad pembukaan rekening. Dalam mengelola dana tersebut, bank tidak bertanggung jawab terhadap kerugian yang bukan disebabkan oleh kelalaiannya. Namun, apabila yang terjadi adalah mis manajemen, bank bertanggung jawab penuh terhadap kerugian tersebut. Ketentuan umum deposito berdasarkan mudharabah : ${ }^{6}$

- Dalam transaksi ini nasabah bertindak sebagai shahib al-mal atau pemilik

- dana, dan bank bertindak sebagai mudharib atau pengelola dana.

- Dalam kapasitasnya sebagai mudharib, bank dapat melakukan berbagai macam usaha yang tidak bertentangan dengan prinsip syariah dan mengembangkannya, termasuk di dalamnya mudharabah dengan pihak lain.

- Modal harus dinyatakan dengan jumlahnya, dalam bentuk tunai dan bukan piutang

- Pembagian keuntungan harus dinyatakan dalam bentuk nisbah dan dituangkan dalam akad pembukaan rekening.

- Bank sebagai mudharib menutup biaya operasional dana deposito dengan menggunakan nisbah keuntungan yang menjadi haknya.

- Bank tidak diperkenankan untuk mengurangi nisbah keuntungan nasabah tanpa persetujuan yang bersangkutan.

\section{Usaha Mikro Kecil Dan Menengah (UMKM)}

Menurut Undang-Undang No. 20 Tahun 2008, yang dimaksud dengan usaha mikro adalah usaha produktif milik orang perorangan dan/atau badan usaha perorangan yang memenuhi kriteria Usaha Mikro. Usaha Kecil adalah usaha ekonomi produktif yang berdiri sendiri, yang dilakukan oleh orang perorangan 
atau badan usaha yang bukan merupakan anak perusahaan atau bukan cabang perusahaan yang dimiliki, dikuasai, atau menjadi bagian baik langsung maupun tidak langsung dari Usaha Menengah atau Usaha Besar yang memenuhi kriteria Usaha Kecil. Usaha Menengah adalah usaha ekonomi produktif yang berdiri sendiri, yang dilakukan oleh orang perorangan atau badan usaha yang bukan merupakan anak perusahaan atau cabang perusahaan yang dimiliki, dikuasai, atau menjadi bagian baik langsung maupun tidak langsung dengan Usaha Kecil atau Usaha Besar dengan jumlah kekayaan bersih atau hasil penjualan tahunan. Usaha Mikro, Kecil, dan Menengah (UMKM) berasaskan :

- kekeluargaan

- demokrasi ekonomi

- kebersamaan

- efisiensi berkeadilan

- berkelanjutan

- berwawasan lingkungan

- kemandirian

- keseimbangan kemajuan

- kesatuan ekonomi nasional.

Adapun kriteria-kriteria usaha mikro adalah sebagai berikut :

- memiliki kekayaan bersih paling banyak Rp50.000.000,00 (lima puluh juta rupiah) tidak termasuk tanah dan bangunan tempat usaha; atau

- memiliki hasil penjualan tahunan paling banyak Rp300.000.000,00 (tiga ratus juta rupiah).

Adapun kriteria-kriteria usaha kecil adalah sebagai berikut :

- memiliki kekayaan bersih lebih dari Rp50.000.000,00 (lima puluh juta rupiah) sampai dengan paling banyak Rp500.000.000,00 (lima ratus juta rupiah) tidak termasuk tanah dan bangunan tempat usaha; atau

- memiliki hasil penjualan tahunan lebih dari Rp300.000.000,00 (tiga ratus juta rupiah) sampai dengan paling banyak Rp2.500.000.000,00 (dua milyar lima ratus juta rupiah).

Adapun kriteria Usaha Menengah adalah sebagai berikut : 
- memiliki kekayaan bersih lebih dari Rp500.000.000,00 (lima ratus juta rupiah) sampai dengan paling banyak Rp10.000.000.000,00 (sepuluh milyar rupiah) tidak termasuk tanah dan bangunan tempat usaha; atau

- memiliki hasil penjualan tahunan lebih dari Rp2.500.000.000,00 (dua milyar lima ratus juta rupiah) sampai dengan paling banyak Rp50.000.000.000,00 (lima puluh milyar rupiah.

Penyaluran pembiayaan perbankan syariah Indonesia ke Usaha Mikro Kecil dan Menengah (UMKM) selama sembilan tahun terakhir (2005-2013) porsi pembiayaan ke UMKM mengalami kecenderungan menurun dari $48 \%$ pada tahun 2005 menjadi tinggal 17\% pada tahun 2012. Dari sisi akad yang digunakan dalam penyaluran pembiayaan, bank syariah memiliki banyak variasi akad yang dibolehkan, yang meliputi : ${ }^{7}$

'1. Murabahah (04/DSN-MUI/IV/2000) dengan akad murabahah

2. Jual Beli Salam (05/DSN-MUI/IV/2000) dengan akad salam, juga salam paralel dengan syarat, akad kedua terpisah dari, dan tidak berkaitan dengan - akad pertama.

3. Jual Beli Istishna (06/DSN-MUI/IV/2000) dengan akad istishna

4. Pembiayaan Mudharabah (07/DSN-MUI/IV/2000) dengan akad mudharabah

5. Pembiayaan Musyarakah (08/DSN-MUI/IV/2000) dengan akad musyiarakah

6. Pembiayaan Ijarah (09/DSN-MUI/IV/2000) dengan akad ijariah.

7. Qardh (19/DSN-MUI/IV/2000) dengan akad qardh.

8. Istishna Paralel (22/DSN-MUI/IV/2000) dengan akad istishna

9. IMBT (04/DSN-MUI/IV/2000) dengan akad ijarah terlebih dahulu, kemudian akad bai' atau hibah, hanya dapat dilakukan setelah masa Ijarah selesai.

10. Pembiayaan Pengurusan Haji (04/DSN-MUI/IV/2000) dengan akad Ijarah atau membantu menalangi pembayaran BPIH nasabah dengan menggunakan prinsip Qardh.

11. Pembiayaan Rekening Koran Syariah (04/DSN-MUI/IV/2000) dengan akad wakalah atau wa'ad

12. Pembiayaan Multi Jasa (04/DSN-MUI/IV/2000) dengan akad Ijarah atau kafalah

13. Line Facility (04/DSN-MUI/IV/2000) dengan akad murabahah, Istishna, Mudharabah, Musyarakah, dan Ijarah. 
14. PRKS Musyarakah (04/DSN-MUI/IV/2000) dengan akad musyarakah dan boleh disertai dengan $w a^{\prime} a d$

15. Musyarakah Mutanaqisah (04/DSN-MUI/IV/2000) dengan akad Musyarakah/Syirkah dan Bai' (jual beli).

16. Sale and Lease Back (04/DSN-MUI/IV/2000) dengan akad Ba'i dan Ijarah yang dilaksanakan secara terpisah

17. Murabahah Emas (04/DSN-MUI/IV/2000) dengan akad murabahah MUI membolehkan selama emas tidak menjadi alat tukar yang resmi (uang).

18. Refinancing Syariah (04/DSN-MUI/IV/2000) dengan berbagai skema akad, yaitu akad musyarakah mutanaqisah, akad al-bai' wa al-isti'jar dan akad albai' dalam rangka musyarakah mutanaqisah.

Namun kenyataannya, pada praktiknya hanya lima akad yang banyak digunakan oleh bank syariah dalam menyalurkan pembiayaannya, yaitu murabahah, mudharabah, musyarakah, qardh dan ijarah. Akad salam pernah digunakan oleh bank syariah di awal tahun 2002 (tercatat Rp. 392 juta pada bulan Maret 2002), namun setelah itu tidak digunakan lagi. ${ }^{8}$

\section{Murabahah}

Transaksi yang saat ini banyak dilakukan oleh bank syariah, baik bank umum syariah, cabang syariah bank konvensional maupun Bank Perkreditan Rakyat Syariah adalah transaksi Murabahah. Menurut Fatwa DSN No. 04/DSNMUI/IV/2000, murabahah adalah menjual suatu barang dengan menegaskan harga belinya kepada pembeli, dan pembeli membayarnya dengan harga yang lebih sebagai laba atau keuntungan. Keuntungan yang diperoleh dari pihak bank syariah dalam transaksi ini merupakan keuntungan jual beli yang telah disepakati secara bersama. ${ }^{9}$

Pada pembiayaan murabahah terdapat fitur dan mekanisme yang diterapkan, antara lain sebagai berikut $:^{10}$

a. Bank bertindak sebagai pihak penyedia dana dalam kegiatan transaksi murabahah dengan nasabah.

b. Bank dapat membiayai sebagian atau seluruh harga pembelian barang yang telah disepakati kualifikasinya.

c. Bank wajib menyediakan dana untuk merealisasikan penyediaan barang yang dipesan nasabah.

Landasan hukum murabahah : 
a. Firman Allah, QS. An-Nisa (4) ayat 29:

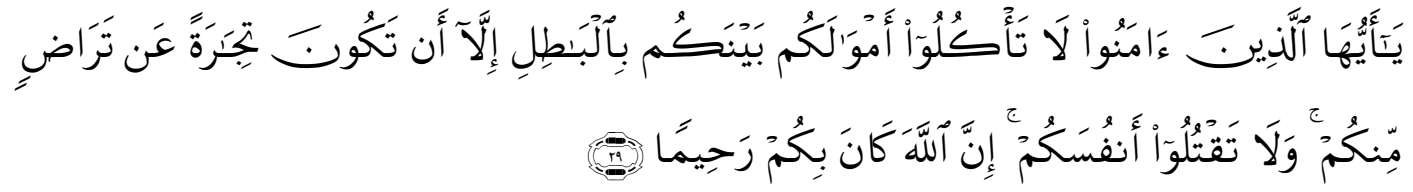

Artinya : "Hai orang-orang yang beriman, janganlah kamu saling memakan harta sesamamu dengan jalan yang batil, kecuali dengan jalan perniagaan yang Berlaku dengan suka sama-suka di antara kamu. dan janganlah kamu membunuh dirimu. Sesungguhnya Allah adalah M aha Penyayang kepadamu."

b. Firman Allah, QS. Al-Baqarah (2) ayat 275 :

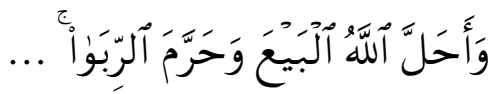

Artinya : "... Dan Allah telah menghalalkan jual beli dan mengharamkan riba..."

c. Hadis nabi SAW, yang berbunyi : "Dari Abu Sa'id bahwa Rasulullah SAW bersabda, "Sesunngguhnya jual beli itu harus dilakukan suka sama suka."

- (HR. Al-Bayhaqiy dan Ibnu Majah, dan dinilai shahih oleh Ibnu Hibban).

d. Ijmak mayoritas ulama tentang kebolehan jual beli dengan cara murabahah (Ibnu Rusyd, Bidayat al-Mujtahid, juz 2, hal. 161; lihat pula al-Kasaniy, Bada'i as-Sana'i, juz 5, h. 220-222).

Manfaat pembiayaan murabahah adalah :

1. Bagi Bank

- Sebagai salah satu bentuk penyaluran dana

- Memperoleh pendapatan dalam bentuk margin

2. Bagi Nasabah

- Merupakan salah satu alternatif untuk memperoleh barang tertentu melalui pembiayaan dari bank.

- Dapat mengangsur pembayaran dengan jumlah angsuran yang tidak akan berubah selama masa perjanjian. ${ }^{11}$

Penjualan Murabahah ini dipergunakan untuk pengadaan barang yang dibutuhkan oleh nasabah. Penjualan ini sesuai untuk yang bersifat konsumtif dan kurang tepat jika diaplikasikan untuk jual beli modal kerja. Ciri-ciri murabahah :

- Penjual (Bank) memberitahu harga pokok pembelian kepada nasabah 
- Bank dapat menawarkan beberapa altenatif keuntungan yang diharapkannya (alternatif harga jual), yang dibedakan berdasarkan jangka waktu pembayaran. Margin keuntungan yang diambil dapat lebih tinggi apabila jangka waktu cicilan lebih lama.

- Nasabah memilih salah satu harga untuk dituangkan nantinya didalam akad jual beli. Tidak boleh ada lebih dari satu harga di dalam akad.

- Bank dan nasabah melakukan akad jual beli dengan spesifikasi barang yang jelas. Bank melakukan pengadaan barang dengan pembelian langsung dari vendor (penyedia) dan selanjutnya menyerahkannya kepada nasabah.

- Bank dapat mengkuasakan kepada nasabah untuk melakukan pembelian barang. Selanjutnya akad jual beli ditandatangani setelah barang dibeli oleh nasabah yang mendapat kuasa (Barang secara prinsip telah menjadi milik bank).

- Bank dapat menerima uang muka atas barang yang akan dijual kepada nasabah.

- Pembayaran dicicil sesuai jangka waktu yang disepakati.

Jaminan dalam murabahah:

a. Jaminan dalam murabahah diperbolehkan, agar nasabah serius dengan pesanannya.

b. Bank dapat meminta nasabah untuk menyediakan jaminan yang dapat dipegang.

Hutang dalam murabahah:

a. Secara prinsip, penyelesaian hutang nasabah dalam transaksi murabahah tidak ada kaitannya dengan transaksi lain yang dilakukan nasabah dengan pihak ketiga atas barang tersebut. Jika nasabah menjual kembali barang tersebut dengan keuntungan atau kerugian, ia tetap berkewajiban untuk meyelesaikan hutangnya kepada bank.

b. Jika penjualan barang tersebut menyebabkan kerugian, nasabah tetap harus menyelesaikan hutangnya sesuai kesepakatan awal. Ia tidak boleh memperlambat pembayaran angsuran atau meminta kerugian itu diperhitungkan.

Penundaan pembayaran dalam murabahah:

a. Nasabah yang memiliki kemampuan dalam hal pembayaran tidak dibenarkan menunda penyelesaian hutangnya. 
b. Dan apabila nasabah sengaja atau salah satu pihak tidak menunaikan kewajibannya, maka penyelesiannya dilakukan melalui Badan Arbitrase Syariah setelah tidak tercapai kesepakatan melalui musyawarah.

\section{Bangkrut dalam Murabahah}

Jika nasabah telah dinyatakan pailit dan gagal menyelesaikan hutangnya, Bank harus menunda tagihan hutang sampai ia sanggup kembali, atau berdasarkan kesepakatan. Uang muka Murabahah (Fatwa DSN No. 13/DSN-MUI/IX/2000)

a. Dalam akad penyaluran dana murabahah, Bank dibolehkan untuk meminta uang muka apabila kedua belah pihak bersepakat.

b. Besar jumlah uang muka ditentukan berdasarkan kesepakatan.

c. Jika nasabah membatalkan akad murabahah, nasabah harus memberi ganti rugi kepada Bank dari uang muka tersebut.

d. Jika jumlah uang muka lebih kecil dari kerugian, Bank dapat meminta tambahan kepada nasabah.

e. Jika jumlah uang muka lebih besar dari kerugian, Bank harus mengembalikan

. kelebihannya kepada nasabah.

Diskon murabahah (Fatwa DSN No. 16/DSN-MUI/IX/2000)

a. Harga (tsaman) dalam jual beli adalah suatu jumlah yang disepakati oleh kedua belah pihak, baik sama dengan nilai (qimah) benda yang menjadi objek jual beli, lebih tinggi maupun lebih rendah.

b. Harga dalam jual beli murabahah adalah harga beli dan biaya yang diperlukan ditambah keuntungan sesuai dengan kesepakatan.

c. Jika dalam jual beli murabahah Bank mendapat diskon dari supplier, harga sebenarnya adalah harga setelah diskon, karena itu diskon adalah hak nasabah.

d. Jika pemberian diskon terjadi setelah akad, pembagian diskon tersebut dilakukan berdasarkan perjanjian (persetujuan) yang dimuat dalam akad.

e. Dalam akad, pembagian diskon setelah akad hendaklah diperjanjikan dan ditandatangani.

Sanksi atas nasabah mampu yang menunda-nunda pembayaran (Fatwa DSN No. 17/DSN-MUI/IX/2000). Sanksi yang dimaksud disini adalah sanksi yang dikenakan kepada nasabah yang mampu membayar tetapi menunda pembayaran dengan sengaja, yaitu: 
a. Nasabah yang tidak/belum mampu membayar disebabkan force majeur tidak boleh dikenakan sanksi.

b. Nasabah yang menunda-nunda pembayaran dan/atau tidak mempunyai kemauan dan itikad baik untuk membayar hutangnya boleh dikenakan sanksi.

c. Sanksi didasarkan pada prinsip ta'zir, yaitu bertujuan agar nasabah lebih disiplin dalam melaksanakan kewajibannya.

d. Sanksi dapat berupa denda sejumlah uang yang besarnya ditentukan atas dasar kesepakatan.

e. Dana yang berasal dari denda diperuntukkan sebagai dana sosial.

Potongan pelunasan dalam murabahah (Fatwa DSN No.23/DSN-MUI/III/2002) :

a. Jika nasabah dalam transaksi murabahah melakukan pelunasan pembayaran tepat waktu atau lebih cepat dari waktu yang disepakati, Bank boleh memberikan potongan dari kewajiban pembayaran tersebut, dengan syarat tidak diperjanjikan dalam akad.

b. Besarnya potongan sebagaimana dimaksud diatas diserahkan pada kebijakan dan pertimbangan Bank.

\section{Tujuan Murabahah}

Akad murabahah digunakan oleh bank untuk memfasilitasi nasabah melakukan pembelian dalam rangka memenuhi kebutuhan akan :

a. Barang konsumsi seperti rumah, kendaraan/alat transportasi, alat-alat rumah tangga dan sejenisnya.

b. Pengadaan barang dagangan

c. Bahan baku dan atau bahan pembantu produksi (tidak termasuk proses produksi)

d. Barang modal seperti pabrik, mesin dan sejenisnya.

e. Barang lainnya yang tidak bertentangan dengan syariah dan disetujui bank.

Harga jual bank :

a. Ketentuan harga jual bank ditetapkan pada awal perjanjian dan tidak boleh berubah selama jangka waktu pembayaran angsuran, termasuk jika dilakukan perpanjangan.

b. Bank harus memberitahu secara jujur harga pokok barang kepada nasabah berikut biaya yang diperlukan. 
c. Apabila nasabah memberikan uang muka (urbun), maka uang muka nasabah tersebut diperlakukan sebagai pengurang Hutang Nasabah (Piutang Murabahah). Namun demikian akad jual beli yang dibuat antara bank dengan nasabah tetap berpedoman kepada harga jual beli awal yang telah disepakati.

d. Bank dapat meminta uang muka pembelian kepada nasabah. Dalam murabahah, uang muka harus dibayarkan oleh nasabah kepada bank, bukan kepada pemasok. Uang muka menjadi bagian pelunasan piutang murabahah apabila murabahah jadi dilaksanakan (tidak diperkenankan sebagai pembayaran angsuran). Tetapi apabila murabahah batal, uang muka dikembalikan kepada nasabah setelah dikurangi dengan kerugian sesuai dengan kesepakatan.

\section{Mudharabah}

Dalam rangka mengembangkan dan meningkatkan dana lembaga keuangan syariah (LKS), pihak LKS dapat menyalurkan pembiayaan dengan cara mudharabah, yaitu akad kerja sama antara pemilik dana (shahibul mal) dan pengelola dana (mudharib), dimana modal $100 \%$ berasal dari pemilik dana (shahibul mal). Landasan hukum mudharabah adalah :

a. $\quad$ Firman Allah, QS. Al-Maidah (5) ayat 1 :

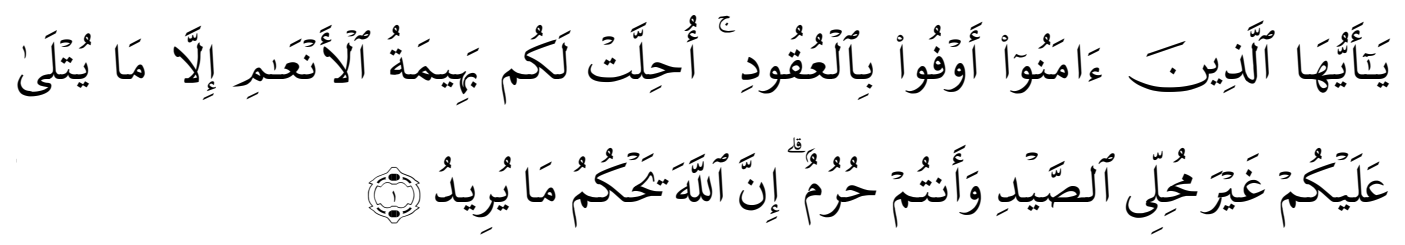

Artinya : "Hai orang-orang yang beriman, penuhilah aqad-aqad itu. Dihalalkan bagimu binatang ternak, kecuali yang akan dibacakan kepadamu. (yang demikian itu) dengan tidak menghalalkan berburu ketika kamu sedang mengerjakan haji. Sesungguhnya Allah menetapkan hukum-hukum menurut yang dikehendaki-N ya."

b. Firman Allah, QS. Al-Baqarah (2) ayat 283 :

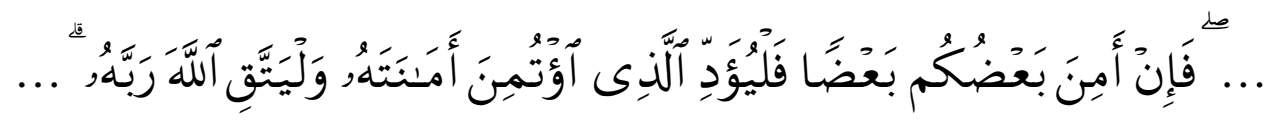

Artinya : "Maka hendaklah ada barang tanggungan yang dipegang[180] (oleh yang berpiutang). akan tetapi jika sebagian kamu mempercayai sebagian yang 
lain, Maka hendaklah yang dipercayai itu menunaikan amanatnya (hutangnya) dan hendaklah ia bertakwa kepada Allah Tuhannya..."

c. Hadis Nabi SAW, yang berbunyi :

"Nabi bersabda, Ada tiga hal yang mengandung berkah: jual beli tidak secara tunai, muqaradhah (mudharabah), dan mencampur gandum kualitas baik dengan gandum kualitas rendah untuk keperluan rumah tangga, bukan untuk di jual." (HR. Ibnu Majah dari Shuhayb).

d. Ijmak.

Diriwayatkan, sejumlah sahabat menyerahkan (kepada mudharib) harta anak yatim sebagai mudharabah dan tak ada seorang pun mengingkari mereka. Karenanya, hal itu dipandang sebagai ijma (Wahbah az-Zuhailiy, al-Fiqh alIslamiy wa Adillatuhu, 1989, 4/838)

e. Qiyas. Transaksi mudharabah diqiyaskan kepada transaksi musaqah.

Beberapa ketentuan hukum pembiayaan mudharabah adalah $:{ }^{12}$

a. Mudharabah boleh dibatasi pada periode tertentu.

b. Kontrak tidak boleh dikaitkan (mu'allaq) dengan sebuah kejadian di masa depan yang belum tentu terjadi.

c. Pada dasarnya, dalam mudharabah tidak ada ganti rugi, karena pada dasarnya akad ini bersifat amanah (yad al-amanah), kecuali akibat dari kesalahan disengaja, kelalaian atau pelanggaran kesepakatan.

d. Jika salah satu pihak tidak menunaikan kewajibannya atau jika terjadi perselisihan di antara kedua belah pihak, maka penyelesaiannya dilakukan melalui Badan Arbitrase Syariah setelah tidak tercapai kesepakatan melalui musyawarah.

\section{Musyarakah}

Kebutuhan masyarakat untuk meningkatkan kesejahteraan dan usaha terkadang memerlukan dana dari pihak lain, antara lain melalui pembiayaan musyarakah. Musyarakah adalah akad kerja sama antara dua pihak atau lebih untuk usaha tertentu di mana masing-masing pihak memberikan kontribusi dana (amal/expertise) dengan kesepakatan bahwa keuntungan dan risiko akan ditanggung bersama sesuai dengan kesepakatan. ${ }^{13}$ Landasan hukum musyarakah:

a. Firman Allah, QS. Al-Maidah (5) ayat 1 : 




Artinya : "Hai orang-orang yang beriman, penuhilah aqad-aqad itu...."

b. Firman Allah, QS. Shad (38) ayat 24 :

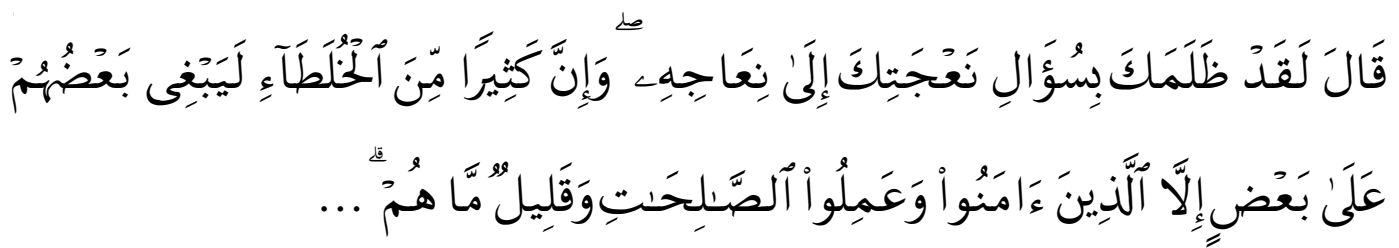

Artinya : "Dan Sesungguhnya kebanyakan dari orang-orang yang berserikat itu sebahagian mereka berbuat zalim kepada sebahagian yang lain, kecuali orangorang yang beriman dan mengerjakan amal yang saleh; dan Amat sedikitlah mereka ini ..."

c. Hadis Nabi SAW.

."Rasulullah SAW berkata : Allah SWT berfirman : Aku adalah pihak ketiga dari dua orang yang berserikat selama salah satu pihak tidak mengkhianati pihak yang lain. Jika salah satu pihak telah berkhianat, Aku keluar dari mereka." (HR. Abu Dawud, yang disahihkan oleh al-Hakim, dari Abu Hurayrah).

d. Taqrir Nabi terhadap kegiatan musyarakah yang dilakukan oleh masyarakat pada saat itu.

e. Ijmak ulama atas kebolehan musyarakah.

Pada pembiayaan musyarakah Bank dan Nasabah bersama-sama memiliki setoran modal didalam usaha yang dijalankan. Bank dan Nasabah berbagi hasil dari keuntungan yang diperoleh. Cara perhitungan keuntungan bagi hasil bulanan dapat didasarkan pada perbandingan modal.

\section{Qardh}

Dalam Bank syariah tidak dibenarkan transaksi peminjaman uang. Apabila dilakukan peminjaman uang, maka harus dikembalikan dengan jumlah yang sama. Apabila terdapat penambahan, maka akan dikategorikan kepada Riba. Karena itu pada Bank syariah yang terjadi adalah jual beli atau kerjasama modal usaha, jadi bukan penyerahan uang dalam bentuk peminjaman. Apabila terdapat peminjaman 
dalam bentuk uang (Al-Qard), maka tidak ada penambahan dalam bentuk apapun. Untuk pinjaman seperti ini di Bank syariah disebut Al-Qardul Hasan (pinjaman tanpa bagi hasil). Landasan hukum al-qardh:

a. $\quad$ Firman Allah, QS. Al-Maidah (5) ayat 1 :

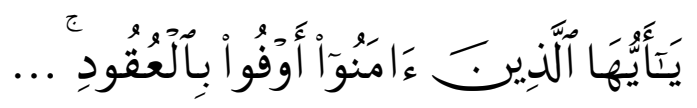

Artinya : "Hai orang-orang yang beriman, penuhilah aqad-aqad itu...."

b. $\quad$ Firman Allah, QS. Al-Baqarah (2) ayat 282 :



Artinya : "Hai orang-orang yang beriman, apabila kamu bermu'amalah tidak secara tunai untuk waktu yang ditentukan, hendaklah kamu menuliskannya..."

c. Hadis nabi SAW,

"Penundaan (pembayaran) yang dilakukan oleh orang mampu adalah suatu kezaliman..." (HR. Al-Jamaah)

Menurut fatwa DSN, ketentuan Umum al-Qardh adalah :

- Al-Qardh adalah pinjaman yang diberikan kepada nasabah (muqtaridh) yang memerlukan.

- Nasabah al-Qardh wajib mengembalikan jumlah pokok yang diterima pada waktu yang telah disepakati bersama.

- Biaya administrasi dapat dibebankan kepada nasabah.

- LKS dapat meminta jaminan kepada nasabah bilamana dipandang perlu.

- Nasabah al-Qardh dapat memberikan tambahan (sumbangan) dengan sukarela kepada LKS selama tidak diperjanjikan dalam akad.

- Jika nasabah tidak dapat mengembalikan sebagian atau seluruh kewajibannya pada saat yang telah disepakati dan LKS telah memastikan ketidakmampuannya, LKS dapat :

$\checkmark$ memperpanjang jangka waktu pengembalian, atau

$\checkmark$ menghapus (write off) sebagian atau seluruh kewajibannya.

Dana al-Qardh dapat bersumber dari sumber dana :

a. Bagian modal LKS

b. Keuntungan LKS yang disisihkan 
c. Lembaga lain atau individu yang mempercayakan penyaluran infaqnya kepada LKS.

\section{Ijarah}

Ijarah adalah transaksi sewa menyewa atas penggunaan asset ataupun jasa.

Bank selaku penyewa memperoleh manfaat dengan memungut sewa atau upah. Karena ijarah adalah akad yang mengatur pemanfaatan hak guna tanpa terjadi pemindahan kepemilikan, maka banyak orang yang menyamakan ijarah ini dengan leasing. ${ }^{14}$ Adapun perbedaannya adalah :

Tabel 1 Perbedaan Ijarah dan Leasing

\begin{tabular}{|l|l|l|}
\hline No & \multicolumn{1}{|c|}{ Ijarah } & \multicolumn{1}{|c|}{ Leasing } \\
\hline 1 & Objek : Manfaat barang dan jasa & Objek : Manfaat barang saja \\
\hline 2 & $\begin{array}{l}\text { Methods of payment : } \\
\text { a. Contingent to performance } \\
\text { b. Not contingent to } \\
\text { performance }\end{array}$ & $\begin{array}{l}\text { Methods of payment : Not } \\
\text { contingent to performance }\end{array}$ \\
\hline 3 & $\begin{array}{l}\text { Transfer of Title : } \\
\text { a. Ijarah : no transfer of title } \\
\text { b. IMBT : Promise to sell or } \\
\text { hibah at the beginning of } \\
\text { period }\end{array}$ & $\begin{array}{l}\text { Transfer of Title : } \\
\text { a. Operating lease : No transfer of } \\
\text { title } \\
\text { Financial lease : option to buy } \\
\text { or not to buy, at the end of } \\
\text { period }\end{array}$ \\
\hline 4 & $\begin{array}{l}\text { Lease Purchase / sewa beli : } \\
\text { Bentuk leasig seperti ini haram } \\
\text { karena akadnya gharar, (yakni } \\
\text { antara sewa dan beli) }\end{array}$ & $\begin{array}{l}\text { Lease Purchase / sewa beli } \\
\text { OK }\end{array}$ \\
\hline 5 & $\begin{array}{l}\text { Sale and Lease Back OK } \\
\text { Sale and Lease Back OK }\end{array}$ \\
\hline
\end{tabular}

Ijarah terbagi dua, yaitu:

a) Ijarah tanpa diikuti pemindahan hak (Operating Lease)

Dengan ijarah ini Bank semata-mata menyewakan aset yang dibutuhkan nasabah pemanfaatannya. Dengan demikian asset ini diakui sebagai aktiva bank dan biaya penyusutannya masuk dalam pembukuan bank. Dapat juga terjadi bank menyewa suatu asset kemudian menyewakan pula kepada nasabah, dengan cara ini berarti hak sewa yang disewakan pula.

b) Ijarah al-muntahiya bi at-tamlik (Financial lease)

Dengan ijarah ini bank membeli asset yang dibutuhkannya kepada nasabah, lalu menyewakannya selama periode yang diperlukan nasabah. Namun pada akhir periode kepemilikan aset itu akan dialihkan kepada nasabah.

Ciri-ciri Ijarah : 
a) Sewa menyewa atas pemanfaatan aset

b) Harga sewa dapat berubah pada waktu perpanjangan kontrak.

Salah satu penyebab cukup besarnya permintaan pembiayaan pada bank syariah terhadap usaha mikro kecil dan menengah (UMKM) karena lembaga ini lebih mengutamakan kelayakan usaha ketimbang nilai agunan, faktor agunan inilah yang bisa menghambat akses usaha kecil terhadap bank konvensional, bukan karena tidak memiliki aset namun aset yang ada tidak dinilai. ${ }^{15}$

\section{Metode Penelitian}

Definisi operasional dari masing-masing variabel dalam penelitian ini adalah tabungan adalah jumlah tabungan yang dapat dihimpun oleh Bank Syariah di Indonesia per bulan dan deposito adalah simpanan berjangka yang dapat dihimpun oleh Bank Syariah di Indonesia per bulan. Populasi dalam penelitian ini adalah data tabungan dan deposito serta pembiayaan sektor UMKM yang disalurkan oleh bank Bank Syariah di Indonesia. Sedangkan sampelnya diambil sebagian dari populasi tersebut yaitu selama 36 bulan Januari 2012 hingga Januari 2015. Dalam dalam penelitian ini dilakukan dengan menggunakan berbagai literatur yang berhubungan dengan masalah yang akan dibahas dan Statistik Perbankan Indonesia - Bank Indonesia (SPS-BI) sebagai sumber data sekunder.

\section{Hasil Pembahasan}

Pertumbuhan setiap bank sangat dipengaruhi oleh perkembangan kemampuannya menghimpun dana masyarakat, baik berskala kecil maupun besar dengan masa pengndapan yang memadai.sebagai lembaga keuangan, maka dana merupakan masalah utama bagi setiap bank. Tanpa dana yang cukup, maka bank tidak dapat berbuat apa-apa atau dengan kata lain bank menjadi tidak berfungsi sama sekali.

Besar kecilnya dana yang berhasil dihimpun oleh suatu bank merupakan satu barometer dalam menilai tingkat kepercayaan masyarakat terhadap bank yang bersangkutan. Sehingga jika suatu bank pertumbuhan dana pihak ketiga (DPK) menunjukkan kecenderungan yang menurun, maka akan dapat memperlemah kegiatan operasional bank. Secara operasional perbankan, dana pihak ketiga (DPK) merupakan sumber likuiditas untuk melancarkan pembiayaan yang terdapat pada sisi aktiva neraca bank. Sehingga makin banyak DPK yang berhasil 
dihimpun oleh bank, maka akan semakin banyak pula pembiayaan yang dapat disalurkan oleh bank tersebut.

Untuk meningkatkan DPK pihak perbankan perlu meningkatkan kualitas pelayanan kepada para nasabah khususnya nasabah yang memberikan dana untuk disimpan seperti tabungan dan deposito. Hal ini diperlukan agar mereka semakin percaya terhadap bank dan semakin merasa nyaman untuk menyimpan dananya ke bank. Sehingga akan semakin besar penghimpunan dana yang dapat dicapai oleh bank yang selanjutnya dapat dialokasikan pada penyaluran kepada UMKM yang semakin besar pula.

\section{Kesimpulan}

Dana Pihak Ketiga yang berupa tabungan, giro dan deposito merupakan beberapa kegiatan operasional perbankan yang wajib dilakukan. Penghimpunan dana oleh pihak bank merupakan kegiatan operasional dalam memperoleh dana dari masyarakat yang nantinya digunakan sebagai penyediaan dana untuk keperluan penyaluran pembiayaan ke sektor UMKM. Laba dari bank itu sendiri diperoleh dari perbedaan pendapatan Pembiayaan dengan penghimpunan dana ditambah dengan biaya operasional. Semakin besar jumlah penghimpunan dana maka semakin besar jumlah pembiayaan yang disalurkan dapat menjadikan perolehan laba yang semakin besar pula.

Besarnya permintaan pembiayaan pada bank syariah terhadap usaha mikro kecil dan menengah (UMKM) karena lembaga ini lebih mengutamakan kelayakan usaha ketimbang nilai agunan, faktor agunan inilah yang bisa menghambat akses usaha kecil terhadap bank konvensional, bukan karena tidak memiliki asset namun asset yang ada tidak dinilai.

\section{Catatan}

1 Bank Indonesia. Perjalanan Perbankan Syariah di Indonesia Kelembagaan dan Kebijakan, serta Tantangan ke Depan. (Jakarta : Bank Indonesia, 2016), h. 270-271.

2 Majelis Ulama Indonesia. Himpunan Fatwa Keuangan Syariah Dewan Syariah Nasional MUI. (Jakarta: Erlangga, 2014), h. 53.

${ }^{3}$ Ibid., h. 52.

${ }^{4}$ Undang-Undang Republik Indonesia Nomor 10 Tahun 1998 tentang Perubahan Atas Undang-Undang Nomor 7 Tahun 1992 Tentang Perbankan.

${ }^{5}$ Ibid., h. 47. 
${ }^{6}$ Ibid., h. 58-59.

${ }^{7}$ Bank Indonesia. Perjalanan Perbankan Syariah di Indonesia. (Jakarta : Grup Riset Kebanksentralan, 2016). h. 280-281.

${ }^{8}$ Ibid., h. 281

${ }^{9}$ Nurul Huda, Mohammad Heykal. Lembaga Keuangan Islam Tinjauan Teoritis dan Praktis. (Jakarta: Kencana Prenada Media Group, 2010), h. 43.

${ }^{10}$ Andri Soemitra. Bank dan Lembaga Keuangan Syariah. (Jakarta : Kencana Prenada Media Group, 2009), h. 79.

${ }^{11}$ Muhammad. Manajemen Dana Bank Syariah.. (Jakarta : Rajawali Pers, 2014), h. 47.

12 Majelis Ulama Indonesia. Himpunan Fatwa Keuangan Syariah Dewan Syariah Nasional MUI. (Jakarta: Erlangga, 2014). h. 84.

${ }^{13}$ Antonio, Muhammad Syafii. Bank Syariah (),2001 h. 90

${ }^{14}$ Adiwarman A. Karim. Bank Islam Analisis Fiqih dan Keuangan. (Jakarta : Raja Grafindo Persada, 2007), h. 140

${ }^{15}$ Hadi, M.K. Wartono. Analisis Usaha Kecil dan Menengah. (Yogyakarta: CV. Andi Official, 2007), h. 14.

\section{Daftar Pustaka}

Antonio, Muhammad Syafii. Bank Syariah dari Teori ke praktik. Jakarta : Gema Insani Press, 2001.

Bank Indonesia. Perjalanan Perbankan Syariah di Indonesia Kelembagaan dan Kebijakan, serta Tantangan ke Depan. Jakarta : Bank Indonesia, 2016.

Hadi, M.K. Wartono. Analisis Usaha Kecil dan Menengah. Yogyakarta: CV. Andi Official, 2007.

Huda, Nurul dan Mohammad Heykal. Lembaga Keuangan Islam Tinjauan Teoritis dan Praktis. Jakarta: Kencana Prenada Media Group, 2010.

Karim, Adiwarman A. Bank Islam Analisis Fiqih dan Keuangan. Jakarta : Raja Grafindo Persada, 2007

Majelis Ulama Indonesia. Himpunan Fatwa Keuangan Syariah Dewan Syariah Nasional MUI. Jakarta: Erlangga, 2014.

Muhammad. Manajemen Dana Bank Syariah. Jakarta : Rajawali Pers, 2014.

Soemitra, Andri. Bank dan Lembaga Keuangan Syariah. Jakarta : Kencana Prenada Media Group, 2009.

Undang-Undang Republik Indonesia Nomor 10 Tahun 1998 tentang Perubahan Atas Undang-Undang Nomor 7 Tahun 1992 Tentang Perbankan. 